\title{
THE SPY POWER, TECHNOLOGICAL INNOVATIONS, AND THE HUMAN DIMENSIONS OF INTELLIGENCE: RECENT PRESIDENTIAL ABUSE OF AMERICA'S SECRET AGENCIES
}

\author{
Loch K. Johnson, University of Georgia
}

\section{Introduction}

The purpose of national security intelligence is to provide policy officials with an advantage in the making of effective policy, based on the collection and analysis of accurate information from around the world that can help to illuminate a decision. Foreknowledge is invaluable in the service of a nation's security; and, in the gathering of useful information, technological innovations in the world of intelligence can result in a stronger shield to protect citizens against the many dangers that lurk across the continents in this uncertain and hostile world.

Among the technological innovations that have allowed the United States to forge one of the most sophisticated intelligence capabilities in history have been:

- Ever greater resolution for cameras on surveillance satellites orbiting the earth or hovering over a battlefield;

- Listening and sensing devices placed on omnibus, as well as niche, satellites in space that can pick up conversations, electronic and radioactive emissions, and other insightful data from the ground below;

- Sea-based sonar devices that can track submarines deep within the seven seas and far beyond the horizon;

- Increasingly capable Unmanned Aerial Vehicles (UAVs) or drones that come in a variety of sizes, from insect and hummingbird dimensions to large aircraft with multiple collection capabilities-all with ever quieter engines, higher resolution cameras, prolonged hovering abilities, and, when necessary, devastating missilry.

- Messaging devices that have come a long way from the secret notes once fastened to the legs of pigeons, relying now on microsecond burst transmissions from asset-to-handler via satellite linkages;

- Communications equipment that now appears to be a harmless packet of cigarettes or a shampoo bottle, rather than a bulky radio transmitter;

- Better-than-Hollywood disguises that can magically transform a James Bond into a Beatrix Potter. 
Upgraded tools for lock-picking, state-of-the-art computer hacking skills, and listening wires that make the Soviet bug inside the U.S. embassy seal in Moscow during the Cold War look as primitive as a Model-T Ford. ${ }^{2}$ The list goes on, especially at a classified level where technological breakthroughs can be found that are far more astonishing than even these remarkable advances known to the public.

Despite all the marvels of modern espionage tradecraft, the governments that rely on them must still deal with the human side of intelligence activities. Unfortunately, arrogance, shortsightedness, laziness, frenetic schedules, and the corrosive influences of power (among other flaws) often lead policy officials to ignore or warp the advantages they could accrue from advanced intelligence spycraft, if they would only use these sources and methods properly. This article examines some of the problems that imperfect human behavior has created for intelligence in the United States at the highest levels of government over the past two decades.

\section{Recent Presidential Leadership and the Spy Power in the United States}

While impressive achievements have been made by the United States and other nations with respect to "techint" (technical intelligence), the men and women in high office for whom this information is intended have frequently failed to appreciate its value; worse still, they have abused the secret agencies that are the sources of the information. These leaders have turned to the intelligence organizations in inappropriate ways or, just as foolishly, they have discounted their relevance altogether. This article presents a capsule chronicle of key human deficiencies that have detracted from the technological successes of the U.S. spy agencies during the three most recent White House administrations, led by Presidents George W. Bush, Barack Obama, and Donald J. Trump.

One of the most important, and disquieting, aspects of the human shortcomings associated with intelligence activities is the gravest threat to any democratic society: the aggrandizement of power within the hands of a single leader - a drift toward autocracy. All too frequently, recent presidents have rejected the prescriptions of the U.S. Constitution, whose drafters went to great lengths in 1789 to ensure that power would never accumulate into the hands of another tyrant, now that the new nation had fought its way out from under the heavy hand of King George III. In place of autocratic rule, power in the new Republic would be dispersed among three branches of government: the executive, legislative, and judicial. "Ambition would be made to counteract ambition," as the leading drafter of the Constitution, James Madison, put it. ${ }^{3}$ 
Above every other goal, the purpose of the Constitution was to hold executive power in check, by the rule of law and the establishment of other centers of governance - Congress and the courts - to share in the making of decisions that would guide the nation's destiny. Under Presidents Bush II, Obama, and Trump, this bedrock principle of "separate institutions sharing power" experienced a troubling erosion, as the United States began a slide toward excessive presidential discretion over intelligence operations - over the spy power, the most secretive and, therefore, the most potentially dangerous of all governmental authorities in a democracy. ${ }^{4}$

\section{Abuses of the Spy Power in the United States}

The war power, the treaty power, and the spy power-each has played an important role in America's relations with the world. The first two were central in the writing of the Constitution. ${ }^{5}$ The spy power, though, remained outside the normal framework of government at the time and, indeed, for the next 186 years. Not until 1975 did investigators on the Church Committee (led by Frank Church, $\mathrm{D}$, Idaho) persuasively argued in the Senate, in the wake of a domestic spy scandal in the United States, that intelligence agencies should be "brought in from the cold" (a British intelligence expression meaning, in this instance, to make the spy agencies more acceptable in a democratic society by insisting that they conduct themselves within the law and honor moral guardrails) (Johnson, 1985). Congress acted in a bipartisan manner to subject the Central Intelligence Agency (CIA) and its fellow organizations in the Intelligence Community (IC) to the same checks-and-balances imposed by the Constitution on the rest of the government. ${ }^{6}$ Lawmakers created new laws and regulations to ensure that America's espionage services were properly harnessed and responsive to the same rules of accountability faced by every other government entity in Washington, D.C. The notion of "intelligence exceptionalism"-secret agencies operating outside the framework of the Constitution-was discarded, out of a concern that the nation's spies and analysts had become too isolated from American values and emphasis on the rule of law.

The U.S. intelligence agencies benefit from having invaluable partners in the development of technological innovations for espionage: the techint companies that manufacture surveillance satellites, along with reconnaissance drones, other spy planes, and a wide array of additional equipment for watching and listening around the globe. They are known generally as "Beltway Bandits," although not all of these corporations have their headquarters buildings located along the traffic loop that circumvents the District of Columbia. At the very time these two vital segments of American society-the IC and the techint companies-were 
working in tandem to develop important intelligence advances for the United States based on the latest technology, the manner in which presidents were dealing with their veiled agencies was beginning to slip backwards. This retrogression at the highest levels of government took the form of a retreat from the application of constitutional principles to intelligence, as well as an increasingly faulty comprehension displayed by presidents and members of the National Security Council (NSC) about the value-added capabilities - facts and thoughtful assessments - the spy agencies could bring to the table.

\section{The New Era of Intelligence Accountability in the United States}

In 1975 the Church Committee uncovered, among other shocking disclosures, that the CIA had engaged in espionage operations directed against anti-Vietnam War protesters-American citizens demonstrating peacefully within their country, in accordance with First Amendment guarantees (Operation CHAOS); the FBI had adopted covert schemes to ruin the lives of these protesters, plus individuals involved in the civil rights movement (Operation COINTELPRO); and the National Security Agency (NSA) had resorted to wiretapping the telephones of American citizens (Operation MINARET) and reading their international cables (Operation SHAMROCK). The CIA, known by insiders as "The Agency," accumulated files on 1.5 million American citizens; infiltrated media, academic, and religious groups inside the United States; and plotted assassinations against foreign leaders in third-world countries. The smear tactics adopted by the FBI in COINTELPRO were intended to blacken the reputations of antiwar and civil rights activists, from the lowliest volunteers to the top leaders, even pressuring the preeminent civil rights leader in the United States, Dr. Martin Luther King, Jr., to take his own life. ${ }^{7}$

Moreover, the NSA leaned on flimsy executive orders from the days of the Truman administration in its conduct of MINARET and SHAMROCK. These operations targeted anti-war protesters and other perceived "subversives" in the United States throughout the next five presidencies (1953-1977: Eisenhower, Kennedy, Johnson, Nixon, and Ford)_never mind Article I of the Constitution that protects peace demonstrations and free speech. Not once did the NSA seek renewed authority for its ongoing surveillance operations from any of the White Houses or from Congress once President Harry S. Truman had left office.

In the aftermath of the Church Committee inquiry, lawmakers moved quickly and in a bipartisan fashion to stretch the constitutional canvas over the full framework of American government, so that it covered the hidden parts as well as the visible ones. The Hughes-Ryan Amendment, enacted in the waning days 
of 1974, forced the president to shed the doctrine of plausible deniability. Henceforth, all significant covert actions - the means by which the CIA attempts to manipulate foreign nations and the course of history through the use of secret propaganda, political and economic machinations, and paramilitary (warlike) activities around the globe-would be formally approved by a president. Further, these approvals had to be reported to the Senate and the House "in a timely fashion" (two days was the understanding). ${ }^{8}$

Then, at the end of its inquiry in 1976, the Church Committee successfully advocated the creation of a permanent standing committee for intelligence accountability, known as the Senate Select Committee on Intelligence (SSCI, pronounced "sissy"). The next year the House followed suit by establishing its counterpart: the House Permanent Select Committee on Intelligence (HPSCI, or "hip-see").

The Congress enacted additional legislation to give these two panels meaningful authority to conduct intelligence reviews. The most important was the Intelligence Oversight Act of 1980. This brief, but far-reaching, statute required the executive branch to report to Congress not only on CIA covert actions but all other significant intelligence activities conducted by each of the spy agencies (as well as any other "entities" assigned intelligence responsibilities, including the staff of the National Security Council or NSC), and prior to their implementation. Here was the powerful ante facto reporting, rather than the earlier Hughes-Ryan standard of an ex post facto informing of Congress. Lawmakers had become genuine partners in the nation's intelligence activities, just as the Constitution had prescribed for every other policy arena. ${ }^{9}$

The vigor and success of congressional accountability over intelligence activities fluctuated throughout the five presidencies that followed the Church Committee investigation (from 1977-2001, which included the Carter, Reagan, George H.W. Bush, and Clinton administrations). The most serious setback to accountability occurred with the Iran-contra scandal during the Reagan years, followed by NSA violations of the law revealed in 2013 by Edward J. Snowden; and the CIA's adoption of a torture program disclosed by SSCI the following year. These intelligence excesses occurred in the crucible of fear in the United States that followed the devastating 9/11 terrorist attacks. ${ }^{10}$

By the advent of the George W. Bush administration in 2001, Congress had become well-establish in the exercise of intelligence oversight. The difference between the pre-Church Committee era of benign neglect toward the America's secret agencies and the post-Committee existence of SSCI and HPSCI was as 
stark as night and day. With the exception of the Iran-contra scandal in the mid1980s, the new intelligence accountability was working out — although exactly how well this experiment in bringing democracy to the dark side of government would fare during the tenures of Presidents Bush II, Obama, and Trump remained a question mark. As events in these administrations unfolded, relations between the governmental branches with regard to the spy power would prove to be fraught.

\section{The Spy Power in the Bush II, Obama, and Trump Administrations}

Presidents Bush II, Obama, and Trump were all less than robust in their embrace of the institutional sharing between the executive and legislative branches of national security powers; the approach prescribed for good governance by the Constitution and successfully promulgated by the Church Committee for intelligence activities. ${ }^{11}$ This institutional sharing is often referred to as the Madisonian model of governance since the eponym, one of the founders and the nation's fourth president, played such a major role in drafting the democratic safeguards found in the Constitution. Bush and Trump especially pushed the boundaries of executive authority over national security intelligence in a manner designed to ensure White House political control over the secret agencies, thereby undermining their credibility and effectiveness as independent, factseeking organizations and relegating Congress to the sidelines. ${ }^{12}$

\section{The Bush II Administration}

The government led by George W. Bush (2001-2008) opened the door to a stark executive branch aggressiveness toward the espionage function of government. Its responses to Iraq provide the most blatant illustrations. The administration:

- attempted, in the lead-up to the 2003 U.S. war against Iraq, to influence the CIA toward adopting the view that Iraq possessed weapons of mass destruction (WMD), with Vice President Cheney visiting the Agency eleven times, always pushing on behalf of this hypothesis (no other vice president had ever visited the CIA even once);

- placed into the State of the Union address in 2002 a reference to a supposed purchase by Iraq's leader, Saddam Hussein, of forty tons of yellow-cake uranium from Niger to construct nuclear weapons, even though CIA research had debunked this rumor (which originated in a flawed Italian intelligence report shared with the United States and 
the United Kingdom) and had urged the president to drop the reference in the speech;

- never ordered the writing of a National Intelligence Estimate (NIE) on Iraq before the invasion, which should have been standard protocol-and was finally demanded by lawmakers, but the document was then too hastily prepared and ambiguous to affect public opinion on the proposed invasion;

- too readily accepted the pro-WMD testimony of Iraqi émigrés in the United States who had escaped the Saddam regime, one of whom claimed to have personally knowledge of unconventional weaponry in Iraqi - only to be revealed as an ambitious politician-in-exile who hoped the United States could bring about regime change and install him as president of the new government in Baghdad;

- failed to listen to important IC agencies in the Departments of Defense, Energy, and State who had significant reservations, based on advanced technological capabilities of the NSA and the National Geospatial-Intelligence Agency (NGA), about some of the "evidence" supporting the WMD argument that should have been further explored before an invasion (as urged unsuccessfully by German and French allies);

- ignored a CIA report, originally prepared in 1995 (and dismissed by the Clinton administration, as well) and updated each year, that warned "aerial terrorism" might come to the United States, with terrorists hijacking and flying U.S. commercial airliners into city skyscrapers-yes, 1995; and,

- waved off further warnings by the outgoing Clinton administration that Al Qaeda was now Threat No. One to the United States, with the Bush national security team failing to hold a NSC meeting on the subject until nine months later (on September 4, 2001). ${ }^{13}$

An additional aspect of the administration's reaction to 9/11 was to encourage the NSA director to flaunt the Foreign Intelligence Surveillance Act (FISA) of 1978, another Church Committee initiative. ${ }^{14}$ Here again, Vice President Cheney played a major role in pushing the President (and the NSA) toward the stance of unilateral White House action in security affairs - a posture often referred to as the "unitary theory" of the presidency. ${ }^{15}$ Cheney ordered the NSA chief, Air Force Lt. Gen. Michael V. Hayden, to return to his agency and unleash its surveillance powers against suspected terrorists, without bothering about warrants beforehand (as lawfully required by FISA). The General returned to NSA Headquarters at Ft. Meade, Maryland, and informed his Office of Legal 
Counsel that "the President is going to do this on his own hook. Raw Article 2, commander-in-chief stuff. No new legislation" (Hayden, 2016, p. 68). Neither the director nor his lawyers bothered to object that this order from the White House flew directly in the face of FISA rules and fell outside the white line of the law. The technological prowess of the NSA is legendary; on this occasion (and others), its constitutional sensitivities proved primordial.

All of these failures of law and protocol were driven by hubris in the White House, fueled by the belief of Cheney and the so-called neo-conservatives ("neocons") in the administration that they knew best, and the President could proceed with war and illegal surveillance, other considerations-such as Article I of the Constitution or FISA requirements - to the contrary notwithstanding. Throughout the build-up to this second invasion of Iraq (the first had taken place in 1990-91), the Congress was of little more use to the body politic than the vermiform appendix is to the human body. Like his father George H.W. Bush, an outspoken critic of the Church Committee reforms, Bush II preferred the era before lawmakers became equal partners in the use of, and supervision over, the nation's secret agencies - the "good old days" when presidents could blithely direct, or ignore, their secret agencies according to the whims and wishes of the White House.

\section{The Obama Administration}

President Obama (2009-2016) had minimal interest in working with Congress when it came to matters of intelligence. For example, he objected to the idea of keeping lawmakers in the "witting circle" on highly sensitive intelligence operations, such as the Osama bin Laden take-down. ${ }^{16}$ During SSCI's investigation into the CIA's use of torture against suspected terrorists, Obama time and again resisted providing documents to investigators - indeed, by executive order, he bottled up over 10,000 pages highly relevant to the inquiry. Further, when the Committee wrote a report despite the President's lack of cooperation, the President refused to declassify even an executive summary of the panel's findings for public consumption, let alone the full report. In addition, Obama moved to lock SSCI's torture report away forever from the public; and, he refused to have even a discussion about the CIA's practice of torture with the Senate's chief investigator on the topic, fellow Democrat Dianne Feinstein (California). These missteps seemed to have been based on misguided advice from former CIA Director John Brennan, who had become Obama's White House adviser on intelligence and related matters. 
Similarly, this President was slow to work with Capitol Hill on developing proper procedures for the use of drones in warfare. This included the establishment of appropriate approval procedures for placing suspected terrorists on the targeting roster (the "kill" or "goodbye" list), even though the use of CIA drone-fired missiles had become the tip of the spear in America's struggle against global terrorism. At the Agency, drones had evolved into the most lethal form of covert action in U.S. history, with these silent killers unleashed in a rising number of attacks in the Middle East, South Asia, and North Africaoften without a partnership role with lawmakers or review by a judicial panel (as required by FISA for wiretaps) in deciding when and where these aerial robots would be deployed (Fuller, 2017). It was a legal oddity: judicial review and warrants for wiretaps, but not for killing people overseas. An example: Obama ordered CIA drones and other surveillance planes to track down the Libyan leader, Muammar el-Qaddafi. Once found, he was executed by local rebel forces. The Obama administration also authorized, via White House decree, the killing of American citizens abroad (including Anwar al-Awlaki) who were suspected of terrorist activities against the United States, but who were never tried in a court of law. ${ }^{17}$

\section{The Trump Administration}

No president has played as fast and loose with America's intelligence agencies as President Trump (2017-2021). The application of constitutional principles to the spy power requires judging secret operations according to democratic tenets, just as happens with the more open agencies and departments. Even before the dramatic intelligence oversight reforms advanced by the Church Committee, certain norms of integrity and honesty guided intelligence professionals. Although a few strayed into illegal domestic surveillance activities, as revealed by the Church Committee probes into Operations CHAOS, COINTELPRO, MINARET, and SHAMROCK, most of these men and women obeyed the law and sought to provide presidents and other policymakers with accurate, timely, and objective intelligence, based on the latest technological capabilities for collection-and-analysis. Yet President Trump began to undermine even these basic expectations.

Trump's first dubious position came early during his presidential campaign in 2016 when, on the analysis side of intelligence, he rejected traditional CIA daily briefings provided to leading candidates. These briefings are a sensible development from the 1960s, based on the notion that a successful contender for the White House ought to arrive at 1600 Pennsylvania Avenue on Day One with a solid knowledge of world affairs, ready to lead the United States in a spiky 
global environment. President Trump found the briefings unhelpful. Sometimes, in fact, intelligence reports do echo what one has already read in the newspapers or heard on CNN; but almost always they include, as well, information derived from clandestine sources that government leaders can benefit from learning.

Once in office, President Trump initially rejected delivery to him of the most important intelligence report prepared by the Intelligence Community, the President's Daily Brief $(P D B) .{ }^{18}$ He later relented, but said he preferred to have an oral briefing rather than read the actual document. As a result of refusing to peruse the $P D B$ (which is only about twenty-five, easily read pages, with figures and graphs in four colors, as well as interesting satellite- and human intelligencederived photography), President Trump lost much of the detail and texture, wherein can lie the truth. The President also said, early in his administration, that neither the chair of the Joint Chiefs of State (C/JCS), the Director of Central Intelligence (D/CIA), or the Director of National Intelligence (DNI) would be welcome at most sessions of the National Security Council, where their presence had been routinely expected and valued by previous administrations. Trump later changed his mind about this prohibition as well, but he still paid only marginal attention to these officials - except for D/CIA Mike Pompeo, a former member of Congress from Kansas who had become his Polonius.

On the eve of his failed re-election bid in November of 2020, President Trumpin a funk over his defeat - cancelled all meetings in the Oval with top CIA briefers, favoring instead a reliance on intelligence reporting from his political appointees. Foremost among them was the newly confirmed DNI, John Ratcliffe, a former Republican member of Congress from Texas. Holding a seat on HPSCI while in Congress, Ratcliffe had a reputation for seldom attending the panel's briefings and hearings. In Washington, he was widely considered the least qualified person to be a leader in the Intelligence Community since the founding of the modern espionage establishment in the United States in 1947. A former CIA officer described the new DNI as a D.C. politician viewed "first and foremost as a political ally [of President Trump] and someone who is on the president's team" (Barnes \& Goldman, 2020).

Further, in a marked breach of tradition and a staggering display of sour grapes after his loss in the 2020 election, Trump refused to allow CIA intelligence briefings for his victorious opponent, Joe Biden, even though these information sessions have been the norm in past presidential transitions. This unprecedented halt to the president-elect briefings placed U.S. national security in jeopardy, by limiting the ability of Joe Biden to be fully prepared to serve as the next chief executive should be. 
Trump was criticized as well, early in his presidential tenure, for selecting an arch right-wing ideologue to serve as D/CIA. Mike Pompeo had been a leader of the Tea Party faction in the House of Representatives and a resolute attack dog against Secretary of State Hilary Clinton. President Trump chose another politician, Dan Coates (R, Indiana), as DNI - although the former Senator and SSCI member turned out to be less partisan than Pompeo.

More than anything else, intelligence is expected to be politically neutral, dedicated to fact-finding and not policy recommendations or partisan stances. Pompeo was not the first politician to head the CIA, but the number has been few and the results have almost always been regrettable. Examples from the past of such appointments include: George H.W. Bush, a former director of the Republican National Committee and a member of the House (R, Texas), selected by President Gerald R. Ford (1976); William J. Casey, the former national presidential campaign director for Ronald Reagan and appointed by the new President (1981); George J. Tenet, a Democrat and former SSCI staff director, chosen by President Bill Clinton (1997); Porter J. Goss, another former House member and HPSCI chair (R, Florida), appointed by President Bush II (2004); and, finally, Leon E. Panetta, a former House member (D, California), placed at the CIA by President Obama (2009). This sums to six individuals, counting Pompeo, who have been former or current politicians picked to serve as CIA chief, out of a total of twenty-three directors since 1947.

Of these men, George H.W. Bush and Panetta usually honored the neutrality principle. Casey, though, was rabidly partisan; Tenet fell into overly friendly relations with the White House; and Goss used the CIA as a bully pulpit to carry on his long-standing public loathing of Hilary Clinton. As for Pompeo, as D/CIA during the Trump administration, he often appeared to be more of a White House aide and policymaker than he was an unbiased spymaster

- even calling for regime change in North Korea, as if he were secretary of state or defense rather than the CIA Director. ${ }^{19}$ Soon, in fact, Trump did appoint him as Secretary of State. Thus, by past standards of respect for political neutrality among intelligence leaders, Pompeo was a sharp departure, in the manner of William Casey, the chief architect of the Iran-contra intelligence scandal in the 1980s.

One of the more widely admired intelligence directors, Richard Helms (19661973) observed that in high-level meetings at the White House what was needed was someone in the room "who was not trying to formulate a policy, carry a policy, or defend a policy; someone who could say: 'Now listen, this isn't my understanding of the facts"” (as cited in Johnson, 2018, p. 471). Pompeo's 
extreme political views, coupled with his policy pronouncements as CIA chief, disqualified him as the trustworthy fact-provider in the room.

Furthermore, unlike any other president, soon after he settled into office Donald Trump lashed out at the CIA and the FBI (in particular, but also the IC writ large). From time to time, other presidents have complained about the intelligence agencies, too, especially when these organizations have delivered bad news to the White House ("The war in Vietnam is failing," was an unwanted message from DCI Helms during the era of President Lyndon B. Johnson); or if they had been unable to anticipate a major calamity (9/11, for example). None, however, had done so as publicly_ or as savagely — as President Trump.

Among Trump's accusations against the IC: it had leaked a secret dossier that alleged he had engaged in sexual improprieties while in Moscow in 2013 (as a private citizen); and, as a consequence, he may have been compromised by Russian intelligence. The allegations in this dossier have yet to be substantiated, nor the source of the leak confirmed. The President claimed, further, that the Obama administration and the FBI had carried out an illegal surveillance against him during the 2016 presidential campaign. This suggestion of political spying by the Obama administration was strongly denied by former President Obama and the Bureau. Clearly, though, and rightly so, an inquiry had been initiated by the Department of Justice and the FBI during the Obama years to examine the validity and implications of widely reported ties between Trump's senior election staff and Russian intelligence officers. Not to have looked into this relationship would have qualified as gross negligence with respect to the FBI's counterintelligence responsibilities. The findings of the Bureau's investigation remain classified.

Further, while the CIA had sworn off waterboarding against suspected terrorists - the subject of the searing inquiry by SSCI's Democratic staffers during the Obama years mentioned earlier-President Trump sang the praises of this form of "enhanced interrogation" as an intelligence gathering technique. He proclaimed during the presidential campaign: "I would bring back waterboarding, and I'd bring back a hell of a lot worse than waterboarding" (Bruck, 2016, p. 34).

President Trump was over the top, as well, in his scathing, ongoing denigration of, and jousting with, America's spy agencies. While visiting Langley (the home of CIA Headquarters in Northern Virginia) in early 2017, he claimed that the intelligence services of the United States were involved in behind-the-scenes plots against him that reminded the President of approaches used by Adolf Hitler 
to defame adversaries during the Third Reich. This comparison astonished and demoralized intelligence officers at the CIA. They had been called nasty things before, but never Nazis. The world of America's spies under this President had fallen into pronounced turmoil.

On the question of how the Trump administration measured up to the postChurch Committee standards of strong intelligence accountability, the story grows grimmer still. Created in 1976, the purpose of HPSCI and SSCI was to stand as checks against the abuse of spy power within the executive branch. Yet HPSCI's chair during the early years of the Trump presidency, Devin Nunes ( $R$, California), seemed to become an extension of the White House within the inner sanctums of the House of Representatives. He met regularly with the President's staff to plan how, as chair, he might best divert the attention of his Committee away from a thorough investigation into possible collusion by Trump with the Russians in derailing Hilary Clinton's presidential campaign in 2016; and whether Trump had known about Russian intelligence efforts to manipulate that election in his favor.

The House Committee was being torn asunder by this coordinated jockeying between the White House and the HPSCI chair. At least on the Senate side of Capitol Hill, the Democratic and Republican leaders at SSCI's helm were attempting to achieve some degree of bipartisan cooperation in that panel's separate inquiry into these topics. The involvement of both committees in these matters was supplementary to another probe being conducted by special prosecutor Robert S. Mueller III, a former FBI Director.

When it came to the spy power, then, President Trump acted in a more unilateral and anti-intelligence manner than any previous president in the modern era. Arguably his departure from tradition was, at any rate, less dangerous than when President Richard M. Nixon endorsed the Huston Spy Plan in 1970, a scheme concocted by the White House to spy on and disrupt antiwar protests inside the United States. ${ }^{20}$ Still, the cozy relationship of the Trump administration with Chairman Nunes was chilling, bordering on what had all the trappings of an attempted coverup regarding ties between the President, his family, and top aides, on the one hand, and the Russian government and its intelligence services, on the other hand.

At the same time that SSCI displayed a devotion to seeing its Russia-probe through to completion without partisan ranker, HPSCI continued to disintegrate along party lines - with Nunes even ordering the construction of a wall between the offices of Democratic and GOP staffers. Further, the Congress passed the 
USA Liberty Act in 2017, with little debate and a willingness to grant the President broadly delegated discretion over the surveillance of suspected terrorists inside the United States, often without a warrant requirement. This law represented a return to the same old "the president knows best" philosophy that haunted a supine Congress in the years prior to the Church Committee investigation - the time that had led to Operations CHAOS, COINTELPRO, and the other domestic spying calamities, not to mention two of the most illconceived covert action initiatives in U.S. history: the Cuban Bay of Pigs fiasco in 1961, and the toppling of the Salvador Allende's democratic government in Chile during the early 1970s.

In addition, the President's advocacy of torture and his renewal of indefinite terms of imprisonment for suspected terrorists at Guantanamo (who were being held without proper legal counsel, let alone a fair trial), along with his ordering of a dramatic increase in the number of drone attacks against suspected terrorists in Somalia and elsewhere, raised further questions about Trump's stewardship over the hidden side of America's government. At the same time, he was interested in having the secret agencies vigorously use their drones and torture skills against suspected terrorists overseas; he often seemed to believe that these organizations comprised a nefarious "deep state" opposed to his administration and committed to its own agenda. The White House brimmed with paranoia and distrust toward the intelligence agencies, while at the same time pursued highly aggressive CIA paramilitary operations-indeed, more so than any other administration in American history. ${ }^{21}$

\section{The Spy Power in Suspension}

The three presidencies examined in this article each exhibited a tendency toward a rejection of Madisonian constitutional principles for policymaking. Each pushed Congress away and embraced a more unilateral presidential approach to foreign policy, national security, and intelligence activities. In the instances of Bush II and Trump, the tendencies toward executive aggrandizement in the realm of intelligence were tethered to a fervent belief in the "unitary presidency," a model of White House supremacy over Congress in all matters related to national security and foreign policy. Even the former constitutional scholar President Obama ended up in this camp, though sometimes more by necessity when a polarized Congress made a policy partnership between the executive and legislative branches difficult, if not impossible, to achieve on some issues. Often Obama's heart and legal mind seemed to bend toward Madison, although his actions largely remained in the camp of Article II devotees. 
What would a respect for Madisonian principles have looked like in these three administrations? It would have required fealty to the Constitution's basic requirement of sharing power between the Congress and the executive, with the courts as occasional arbiters. If serious disagreements occurred between the two action branches, then the executive should have backed away from its policy objectives; without the support of the American people, as reflected in the stances of their representatives in the House and Senate, a president should keep clear of major initiatives in the national security and foreign policy domains. Furthermore, this leadership triad should have named non-political figures, or at least non-ideological lawmakers or former lawmakers (like George H.W. Bush, Coats, and Panetta), to head the intelligence agencies, instead of individuals at the extreme wings of their party. Pompeo was an especially dubious pick, allowing a Tea Party stalwart to lead the non-partisan CIA. At every opportunity, the presidents should have placed intelligence above politics-as-usual.

Also, Bush II, Obama, and Trump could have worked more closely with lawmakers on improving procedures for the approval of drone targeting lists, especially when American citizens were in the crosshairs. Moreover, the presidents could have shared intelligence across the board with SSCI and HPSCI, in a more systematic, regularly, and timely manner. President Trump, in particular, was in violation of the legal reporting requirements laid out in the 1980 and 1991 Intelligence Oversight Acts when he failed to consult with senior SSCI and HPSCI members (the "Gang of Eight") before the assassination of the Iranian senior policy official Qasem Soleimani in January of 2020 — an extreme covert action against a non-combatant, and a rash act that invited retaliation against U.S. officeholders. Soleimani was a non-combatant and this hit should have been a CIA responsibility with reporting under Hughes-Ryan to the senior lawmakers (a so-called Article 50 assassination, named after its number in the legal code of intelligence statutes), instead of using a military drone that requires no congressional reporting (Article 10). ${ }^{22}$ As well, Trump should have stayed far away from trying to turn HPSCI chair Nunes into a fifth column for the administration.

These are serious defects that marred all three administrations. The evocation of an imperial presidency tilted America's government far away from a focus in the White House on important technological innovations in intelligence and the important products these advances can yield. Human foibles hindered the valueadded potential of the secret agencies, buffeted as they have been by political disputes; attempts to cherry-pick their assessments; clashes between the branches over intelligence accountability; verbal attacks by President Trump 
against former D/CIA Brennan and DNI Clapper, as well as the incumbent DCIA Gina Haspel; the President's firing of the DNI's Inspector General; and a cavalier attitude in the White House toward the usefulness of the secret agencies in decision-making. ${ }^{23}$ The end result: a waste of the nation's investment in intelligence innovations and activities that can provide presidents and lawmakers with cat's eyes in the dark.

Part of the problem stemmed from the fact that these three presidents had little knowledge about intelligence prior to their election to the nation's highest office, especially Trump (who seemed to have limited knowledge about any function of modern government). When individuals like George Washington and Dwight David Eisenhower have been in the White House (military personnel who understood that battles are won with superior intelligence), or George H.W. Bush (the only president to have served as the nation's spymaster and, therefore, arriving at the White House with a hands-on knowledge of the value of these agencies), the secret agencies receive the attention they deserve as deep reservoirs of knowledge about international events and conditions.

Presidents who appreciate the gift of reliable information have turned to their intelligence agencies every day with attentiveness to their reports, realizing that the data and analysis they provided is based in large part on cutting edge technology that is unique in the world. The American electorate would do well to evaluate their presidential candidates according to how well these men and women are likely to appreciate and manage these vital wellsprings of global information. Absent a serious level of interest from the White House in national security intelligence, the $\$ 80$ billion secret agencies become just so many selflicking ice cream cones.

\section{Intelligence and Democracy}

What direction will the United States take in the future when it comes to the spy power? Will the constitutional model advanced by Madison and his colleagues attract the respect it has enjoyed for most of America's history; or will the Richard Nixons, Dick Cheneys, and Donald Trumps of the world hold sway, allowing presidents to become ever more imperial?

In his magisterial study of the Roman Empire, the British historian Edward Gibbon cautioned that "constitutional assemblies form the only balance capable of preserving a free-constitution against enterprises of an aspiring prince" (Gibbon, 1952, p. 85). America's founders understood this historical truth and enshrined it in the Constitution. That document's safeguards against the abuse 
of power were their greatest innovation, and the most important gift they gave to the young Republic. Whether current and future generations in the United States will appreciate and honor these safeguards in the realm of intelligence is a matter of ongoing debate from Hawaii to Maine. The "unitary" theory of the presidency and its strident worshipers of centralized authority are always hovering near and sometimes in control of the White House-and, ironically, even key positions in the Congress, the very institution created by the founders to guard America's freedoms against the accumulation of powers into the hands of a president.

The United States, Canada, and other countries will continue to push forward on the boundaries of techint innovation, as the search goes forward for better ways to protect the democracies against enemies at home and abroad. But will the democracies choose leaders who understand and appreciate the technologicalbased capabilities of their secret services and the advantages these capabilities can provide for improved decision-making? And will they honor the idea of accountability for the secret agencies, even in - most especially in - the darkest corridors of power? 


\section{References}

Barnes, J. E., \& Goldman, A. (2020, October 31). Trump is said to set aside intelligence career intelligence briefer to hear from advisers instead. New York Times.

https://www.nytimes.com/2020/10/30/us/politics/trump-intelligencebriefings.html

Bruck, C. (2016, August 1). The Guantánamo failure. The New Yorker.

Fuller, C. J. (2017). See it/shoot it: The secret history of the CIA's lethal drone program. New Haven, Connecticut: Yale University Press.

Gibbon, E. (1952). The decline and fall of the Roman Empire. New York: Viking.

Hayden, M. V. (2016). Playing to the edge: American intelligence in an age of terror. New York: Penguin.

Johnson, L. K. (1985). A season of inquiry: The senate intelligence investigation. Lexington: University Press of Kentucky.

Johnson, L. K. (2018). Spy watching: Intelligence accountability in the United States. New York: Oxford University Press. 


\section{Footnotes}

${ }^{1}$ For illustrations in the public literature of modern techint in the domain of satellite camera-surveillance (imint or "imagery intelligence"), see Bruce Berkowitz, The National Reconnaissance Office at 50 Years: A Brief History (Chantilly, VA: U.S National Reconnaissance Office, Center for the Study of National Reconnaissance, Washington, D.C., 2011); Dino A. Brugioni, From Balloons to Blackbirds: Reconnaissance, Surveillance and Imagery intelligence, How It Evolved, The Intelligence Professional Series, No. 1 (McLean, VA: Association of Former Intelligence Officers, 1993); on listening and sensing devices in space, Matthew M. Aid, The Secret Sentry: The Untold History of the National Security Agency (New York: Bloomsbury Press, 2009), and underwater, James Bamford, The Puzzle Palace: Inside the National Security Agency (New York: Penguin, 1983), and Jeffrey T. Richelson, The US Intelligence Community, $7^{\text {th }}$ ed. (Boulder, Colorado: Westview, 2016); on drones as intelligence-collection platforms, Sarah E. Kreps, Drones: What Everyone Needs to Know (New York: Oxford University Press, 2016); on asset communications with their handlers, Frederick P. Hitz, The Great Game: The Myth and Reality of Espionage (New York: Knopf, 2004); and on CIA disguises, Antonio J. Mendez with Malcolm McConnell, The Master of Disguise: My Secret Life in the CIA (New York: Morrow, 2000). Insightful general works on techint include: Robert M. Clark, The Technical Collection of Intelligence (Washington, D.C: CQ Press, 2011); Mark M. Lowenthal, Intelligence: From Secrets to Policy $7^{\text {th }}$ ed (Thousand Oaks, CA: CQ Press/SAGE, 2017); Mark M. Lowenthal and Robert M. Clark, eds., The Five Disciplines of Intelligence Collection (Washington, D.C.: CQ Press, 2016); and Robert Wallace and H. Keith Melton, with Henry Robert Schlesinger, Spycraft: The Secret History of the CIA's Spytechs, from Communism to Al-Qaeda (New York: Penguin Plume Book, 2009).

${ }^{2}$ On the Soviet spy caper against the U.S. Embassy in Moscow during the Cold War, see George F. Kennan, Memoirs, 1950-1963, Volume II (New York: Little, Brown \& Co., 1972): 155-56.

3 “Paper No. 51," The Federalist (New York: Modern Library, 1937): $335-41$.

${ }^{4}$ This description is from the famed presidential scholar, Richard E. Neustadt, Presidential Power (New York: Wiley, 1960): 33. 
${ }^{5}$ See Loch K. Johnson, American Foreign Policy and the Challenges of World Leadership: Power, Principle, and the Constitution (New York: Oxford University Press, 2015).

${ }^{6}$ Final Report, Select Committee to Study Governmental Operations with Respect to Intelligence Activities (Church Committee), Report No. 94755, U.S. Senate, $94^{\text {th }}$ Cong., 2 d Sess. (April 23, 1976). The author served as a senior aide to Senator Church during this inquiry.

${ }^{7}$ On these and the following controversial intelligence operations, see the Church Committee, Final Report, ibid.

${ }^{8}$ An amendment to the Foreign Assistance Act of 1974, Pub. L. No. 93559, 32, 88 Stat. 1795, 1804 (1974).

${ }^{9}$ Title V of the National Security Act of 1947 (50 U.S.C. 413), Accountability for Intelligence Activities: The Intelligence Oversight Act of 1980), Pub. L. No. 96-450, 94 Stat. 1975 (1981).

${ }^{10}$ See Karen J. Greenberg, Rogue Justice: The Making of the Security State (New York: Crown, 2016); Loch K. Johnson, Spy Watching: Intelligence Accountability in the United States (New York: Oxford University Press, 2018).

${ }^{11}$ See Johnson, Spy Watching, ibid.

${ }^{12}$ For a provocative analysis that is highly pessimistic about the chances that Madisonian checks-and-balances can stand up successfully against forces in Washington, D.C. that favor government authority centralized into the hands of the executive branch, see Michael J. Glennon, National Security and Double Government (New York: Oxford University Press, 2015).

${ }^{13}$ On these points, see Richard A. Clarke, Against All Enemies: Inside America's War on Terror (New York: Simon \& Schuster, 204), pp. 229, 237; Robert Jervis, Why Intelligence Fails: Lessons from the Iran Revolution and the Iraq War (Ithaca: Cornell University Press, 2010); and Loch K. Johnson, The Threat on the Horizon: An Inside Account of America's Search for Security after the Cold War (New York: Oxford University Press, 2011).

1450 U.S.C. 1801-1811 (Supp. V 1981), enacted in 1978.

${ }^{15}$ For this theory of the presidency, see John Yoo, The Powers of War and Peace: The Constitution and Foreign Affairs after 9/11(Chicago: University of Chicago Press, 2010).

${ }^{16}$ See Leon Panetta [CIA Director in the Obama Administration] and Jim Newton, Worthy Fights: A Memoir of Leadership in War and Peace (New York: Penguin, 2014): 299. 
${ }^{17}$ For a case study of the al-Awlaki assassination, see Scott Shane, Objective Troy: A Terrorist, a President, and the Rise of the Drone (New York: Tim Duggan Books, 2015).

${ }^{18}$ While serving as a senior aide to former Secretary of Defense Les Aspin when he chaired the Aspin-Brown Presidential Commission on Intelligence in 1995, the author reviewed many $P D B$ s for the commissioners, comparing these top-secret documents with leading newspaper reporting (see Johnson, Horizon, op.cit.).

${ }^{19}$ Remarks, Aspen Institute Forum, Aspen, Colorado (July 20, 2017).

${ }^{20}$ See Loch K. Johnson, America's Secret Power: The CIA in a Democratic Society (New York: Oxford University Press, 1989).

${ }^{21}$ PBS News Hour reported on the increase in drone attacks (February 26, 2018); see also, Greg Jaffe, “Trump Administration Reviewing Ways to Make It Easier to Launch Drone Strikes," Washington Post (March 13, 2017), p. A1. For a comparison of the frequency with which covert actions have been adopted by these administrations, see Johnson, Spy Watching, op.cit.

22 See Johnson, Spy Watching, op.cit.

${ }^{23}$ An illustration of the Trump family's disdain for intelligence officers could be seen in a remark by Donald J. Trump, Jr., who on Twitter referred to CIA Director Haspel as a "trained liar" [Julian E. Barnes, "An Intramural Republican Fight Breaks Out Over the C.I.A. Director's Fate," New York Times (November 11, 2020): A16].

(c) $(1) \Theta($

EY NC ND This work is licensed under a Creative Commons AttributionNonCommercial-NoDerivatives 4.0 International License.

(C) Loch, Johnson, 2021

APA Citation:

Johnson, L. K. (2021). The spy power, technological innovations, and the human dimensions of intelligence: Recent presidential abuse of America's secret agencies. The Journal of Intelligence, Conflict, and Warfare, 3(3), 1-21.

Published by the Journal of Intelligence, Conflict and Warfare and Simon Fraser University Available from: https://jicw.org/ 